\title{
FROM INTUITION TO REALITY: MEASURING FEDERAL POLITICAL CULTURE IN AUSTRALIA
}

\author{
A J Brown \\ Professor of Public Law \\ Centre for Governance \& Public Policy \\ Griffith University, Australia
}

\begin{abstract}
:
Federalism is associated with a range of political values, but their institutionalisation in practice varies significantly. This article uses a new empirical approach to measuring "federal political culture" through the Australian Constitutional Values Survey, to explore this gap between theory and reality. It presents analysis by gender to demonstrate the approach, highlighting the importance of resolving the mix of theory and practice needed to understand contemporary preferences in institutional design. Overall, Australians were shown to be predominantly federalist in their values. However, women were on average somewhat stronger federalists than men, being stronger supporters of decentralism and legal diversity, while also being somewhat less likely than men to consider that Australia's present system delivers adequately on these values. The findings contribute to federal reform debates.
\end{abstract}

[RUNNING HEAD:

FEDERAL POLITICAL CULTURE IN AUSTRALIA 
'Federal political culture' has been described as 'a set of orientations toward the federal political system and attitudes towards the role of self... in the system' (Duchacek 1987: 341; see Cole et al 2004: 214). More specifically, it can be understood as the extent to which the political attitudes and beliefs of a population reflect attachment to key values associated with federalism. Citizen attitude surveys in North America in 2004 and 2009 indicate that federal political culture is a viable concept that can be operationalized for empirical research. Its measurement can serve to inform trends in intergovernmental relations, supplying a predictor of public receptivity to shifts in relationships between levels of government, and a barometer of political health and harmony by identifying the degree of alignment between institutions, political practices and public preferences (Cole et al 2004: 201; Kincaid \& Cole 2010: 72).

This article presents select results from a parallel foray into the measurement of federal political culture, through Australian Constitutional Values Surveys conducted by the author and colleagues in 2008 and 2010. ${ }^{1}$ The first two parts outline the theoretical background to, followed by the logic and aggregate results of, this related but different approach. In the context of contemporary Australian reform debates, the exercise both reinforces and extends the benefits identified by Kincaid and Cole. The third part demonstrates the potential utility of the approach for other jurisdictions, by using it to throw light on an important contemporary issue: the relation between women's politics and federalism. Internationally, a growing literature on whether federal institutional architecture serves to impede or advance gender equality has become important, not only for its own sake, but as an empirical testing-ground for gaps between the rhetoric and reality of federalism in different contexts. In particular, a frequently presumed value of federal systems is that they permit customisation and control of public policy in ways that 
better meet local and regional of community needs (including gender equality), as well as providing more opportunities for participation (including by women) in political life. As Gwendolyn Gray notes, such claims are 'intuitively persuasive: when vast geographical areas are divided into smaller jurisdictions, it should be easier to tailor policies accordingly'. However:

[W] hen we examine the proposition more closely, it loses some of its persuasiveness. Why should the levels of government in a federal system be better able to tailor policies to local needs than the different levels of government in unitary systems? (Gray 2010: 23)

Accordingly, the fourth part of the article uses the sometimes subtle differences in Australian men's and women's attitudes towards federalism, including levels of federal political culture, to throw additional light on the responsiveness of federal systems in reality. These differences are useful in exposing important issues of constitutional development and institutional design. While the resulting evidence of considerable resonance between women's attitudes and federal values may challenge some feminist scholarship, it also supports other elements of this scholarship in at least three ways: by confirming that whether federal architecture serves women's priorities is

highly context dependent; by showing that even if just as strong or stronger in their attachment to federal values, more women are sceptical as to whether federalism's key values are actually being adequately achieved; and by revealing different preferences for future reform.

\section{Federal Political Culture}

'Federal political culture' (Duchacek 1987: 341; Cole et al 2004: 214) can be seen as one subset of political culture more generally - defined in Australia to mean citizens' 'collective assumptions' about governing institutions and processes, embedded in wider power relationships and 'woven in various ways into their assumptions about other parts of life' (Smith 2001: 5). In 
this article, federal political culture is taken to mean the extent to which the political attitudes and beliefs of a population reflect attachment to key values associated with federalism. In the past, as noted by Duchacek, measurement of federal culture has focused on the extent to which constituent units of federations command the trust, loyalty and identification of their citizens, relative to the whole. In Australia, where criticism of federalism has drawn on the nation's apparent cultural and political homogeneity, empirical evidence of State differences in political attitudes has also been used to support claims of federal political culture (Holmes \& Sharman 1977; see Smith 2001: 282).

While both these types of data continue to be important to understanding federal political culture, they have limitations. Australia's conditions demonstrate that key State differences in political values may be more likely to have institutional explanations, than simply sociological ones (Denemark \& Sharman 1994). As noted by Gray at the outset, local and regional identification can also be expected in non-federal systems. Further, while State differences in attitudes may reinforce the continuing significance of the "compact" dimensions of federations formed by negotiated union, in practice any federal process tends to be dynamic - either 'one of bringing together dissociated states or one of disaggregating a centralized state' (Kincaid 1995: 32). In Australia, it has long been neglected that both federal and unitary theories of constitutional design took hold at the same time, in conflicting ways, leaving unfinished territorial business which continues to resonate in reform debates to this day (Brown 2004; 2006).

Internationally, research has thus begun to directly test for the presence and role of federal political values in citizen attitudes. In 2004 and 2009, Kincaid and colleagues used nationally distributed random representative samples to collect evidence of federal political culture in North 
America's federations, by testing respondents' level of agreement with the following three statements (Cole at al 2004; Kincaid \& Cole 2010):

1. 'A federal form of government, in which power is divided between a national government and state/provincial and local governments, is preferable to any other kind of government' (agreement is considered pro-federal culture);

2. 'A country in which everyone speaks the same language and has similar ethnic and religious backgrounds is preferable to a country in which people speak different languages and have different ethnic and religious backgrounds' (disagreement is pro-federal culture);

3. 'When making decisions, government is better off limiting discussion and participation to the fewest groups and opinions as possible, rather than involving a wide variety of groups and opinions' (disagreement is pro-federal culture) (2009).

These questions highlight the complexity of defining these values. Drawing on a diverse literature (see Cole at al 2004: 214-216; Kincaid \& Cole 2010: 67-68), they reflect three attributes of political systems and behaviour which are core to the perceived value of federalism: constitutional division of political power on geographic or demographic lines; tolerance of diversity; and greater rather than fewer opportunities for political participation.

As asked to date, these questions also mix institutional, sociological and behavioural factors in their investigation of 'federal culture' (cf Denemark \& Sharman 1994). Importantly, each attribute can also involve strong relationships with other political concepts. For example, the basic concept of divided power is related to wider conceptions of 'moderate' and republican government central to modern liberal democratic traditions, including other formal but nongeographic divisions of power (Galligan 1995: 16-19, 39). For Cheryl Saunders, this 'tradition of limited government' is an 'important adjunct' to federalism, likely as important as any federation's formal constitutional arrangements (Saunders 1995: 78).

Diversity is an even more complex value, especially if the testing is limited to the value placed on cultural diversity defined in linguistic, ethnic and religious terms. This approach accords with 
Daniel Elazar's assessment that a society which is truly 'thinking federal' must be 'comfortable with the political expression of diversity' in all forms, but does not necessarily tie back directly to factors of state architecture, and may not be as transferable where other dimensions of diversity are more important. In Australia, institutionalised capacity for political and policy diversity is identified as valuable where it permits 'customisation of policies to meet local needs [and] differences in climate, geography, demography, culture, resources and industry' (Twomey \& Withers 2007: 4). Policies that impede or promote gender equity and equality, discussed below, also fall on this wider spectrum of reasons for valuing political diversity.

Thirdly, how to test for the value of opportunities for political participation is more complex again. The presence of more and stronger subnational political fora than may exist without federalism tends to flow as a consequence of the first two values - in Australia, the hope is that federalism helps bring 'democracy closer to the people, allowing them to influence the decisions that affect them most' (Twomey \& Withers 2007: 4). However, a general culture of plurality and inclusiveness is probably no less desirable, and theoretically just as capable of achieving its expression via other means, in non-federal systems. Like other values, this attribute is linked with a vision of modern federalism as associated with advantages of 'peace, security, liberty, democracy, innovation, efficiency, and equity' (Kincaid 1995); or, similarly, of 'economic efficiency, democratic participation and the protection of personal rights and liberties' (Inman 2007: 525). These goals are likely to be valued in the political cultures of many nations, irrespective of their exposure to federal traditions, and may not necessarily help get 'inside the box' of federal political culture as a lived reality (Fafard et al 2010: 23). 


\section{AUSTRALIAN CONSTITUTIONAL VALUES}

The approach adopted in the Australian Constitutional Values Survey was to specifically tie these key concepts back to the desirability of elements of state architecture, or institutional design, closely associated with federal systems. The approach may also better allow comparisons of federal political culture between countries that may or may not fit the definition of federations - for example, none of the survey items used the term 'federal' at all. Two Australian surveys have been conducted to date, in May 2008 and March 2010, with this article reporting the more recent results. ${ }^{2}$ The approach is exploratory, as a first ever attempt to directly measure public attachment to key federal values via this method. Respondents were also asked about their sense of belonging to different governance scales, their perceptions of the relative performance and effectiveness of different levels, and their preferences for their system of government in the future (for more detail see Brown 2009; Brown 2012a; Brown 2012b).

To test for strength of federal political culture, respondents were asked for the level of desirability they attached to each of seven different features of a system 'having different levels of government'. Table 1 shows the four features most directly reflective of federal, as opposed to non-federal theory, selected for the present analysis. The first feature corresponds most closely with the North American question, testing the value placed on division of power between different levels. The second feature focuses on institutional capacity for diversity, as against the sociological value of diversity - and defines this in terms of legal diversity ('different laws in response to varying needs and conditions') in order to link directly to state architecture. The third feature tests for the value of having more sites for political participation, but by linking directly to the perceived advantage of having multiple elected parliaments. The fourth feature ('different governments arguing over who is responsible for a particular problem') was included because it 
tests a further, defining element of federal systems which is not otherwise measured - the deliberate harnessing of 'competition and conflict' (as emphasised by Wildavsky: see Kincaid \& Cole 2010: 67-68), especially for purposes of accountability. As in Canada (Fafard et al 2010: $29,41)$, the 'capacity to pit one level of government against another' has been advanced as a significant explanation of federalism's salience in Australia (Smith 2001: 305).

These four items do not combine to form any reliable scale, because as seen from the above, federal political culture is anything but a neat concept: 'federalism has the task of reconciling principles that are, prima facie, contradictory' (Fafard et al 2010: 21). This was confirmed by reliability analysis ${ }^{3}-$ the selected items do not tend to measure the same concept, but rather, may pull in different directions. It is by exposing points of conflict and confluence between these values that the results help answer questions about political culture. In Australia, this includes the dilemmas posed by competing descriptions of Australians' relationship with federalism as 'overwhelmingly supportive' (see Smith 2001: 305), 'love-hate' and 'schizophrenic' (Galligan 1995: 53, 62), and suffering from a 'lack of a federal culture receptive to power sharing' (Saunders 2000: 269, 284; see Brown 2012a).

In Table 2, the aggregate results give an overall picture of Australian federal political culture by grouping respondents according to particular logical combinations of responses. At the extremes, respondents who find all four features to be desirable are defined as 'strong federalists'; while those who find all four to be undesirable, are defined as 'strong non-federalists'. In between, respondents who see desirability in both (a) division of power and (b) legal diversity are defined as 'clear federalists' even when finding either or both the other features to be undesirable; while respondents who see both division of power and legal diversity as undesirable are 'clear nonfederalists', even if they see value in either or both of the other features. The middle groups are 
those who see desirability in either division of power or legal diversity, but not both. These respondents are defined as 'conflicted' federalists or non-federalists due to the close relation between these concepts (i.e., legal diversity largely presupposes at least some division of power, and division of power largely guarantees at least some legal diversity).

Insert Tables 1 and 2 about here

Overall, this analysis tends to confirm Australia's political culture as predominantly 'federalist', but with very significant tensions. Sixty-six per cent of adult citizens can be classified as such, the common denominator being the perceived desirability of 'having power divided up between different levels'. By contrast, only around 25 per cent of citizens are classed as 'non-federalist'. However, the facts that almost a third of adults ( 32 per cent) fall into the 'conflicted' bands, and less than half of citizens appear to count as 'clear' to 'strong' federalists, helps explain some of the complex dynamics of Australian public debate and political behaviour. Consistently with previous indications (e.g. Denemark \& Sharman 1994), different Australian States were also confirmed to have different levels of federal political culture. For example, only 40 per cent of New South Wales adults counted as 'strong/clear' federalists, while in Western Australia, the proportion rose to 51 per cent (see Brown 2012a: 324).

Conversely, the results can also help clarify the values of those with differing reform preferences. Despite being predominantly federalist in their values, a majority of citizens (66 per cent in 2008, and 75 per cent in 2010) described the system of government they thought Australia should have 'in the future, say 20 years from now', in terms structurally different to the system today. The single most popular group of reform preferences revolve around the ostensibly 
radical option of abolishing and/or replacing Australia's existing States. However, contrary to some hypotheses, reformist respondents were not necessarily less federalist nor more centralist than those favouring the status quo - and were often more federalist, and less centralist (see Brown $2012 \mathrm{a} \& \mathrm{~b}$ ). Such results confirm both the feasibility and utility of federal political culture as a tool for more accurately diagnosing what citizens are seeking from their political system in a rapidly changing world.

\section{GENDER, DECENTRALISM AND LEGAL DiVERSITY}

Can this approach shed light on issues of general interest in intergovernmental relations, in addition to Australian idiosyncracies? In particular, do constitutional values vary by gender among Australian adults, and if so, can such variations throw light on how well or poorly a federal system is perceived as aligning with the political preferences of the communities it is meant to serve? As asked by Gray (2010: 23) as the outset, 'intuitively persuasive' claims about the responsiveness of federal systems may not translate into reality - a problem central to an important literature on how well or poorly federal systems accommodate priorities of gender equity and equality (see e.g. Haussman et al 2010; Chappell et al 2012). Important in their own right, questions of whether women's interests are being served also have wider implications. If values of diversity and participation are not being realised by and for women, in a country like Australia, it is difficult to see how well they can be achieved for society as a whole.

As Jill Vickers notes (2010: 419-420), there are three recent schools of thought regarding the relationship between federalism and women's interests. The first is that federal systems generally disadvantage women. Most authors in the collective study of feminism and federalism led by 
Vickers, Haussman and Sawer (2010: 234) shared the view that national governments are better able than constituent ones to advance the social and economic rights needed for equal citizenship, in ways that make the supposed advantages of subnational legal diversity something of a chimera:

[O]ne general defence of federalism as a system of governance is its capacity to promote policy diversity... [but] such policy diversity may be incompatible with the uniform social policy and welfare-state programs sought by more egalitarian forms of feminism.

A second school of thought is that federalism does provide positive opportunities for women's interests to be served by providing multiple sites for action, leading to innovation and jurisdictional transfer of advances, in addition to diversity and participation. For example, at least one recent study of feminist-inspired violence against women (VAW) policy in Australia shows that 'the purported benefits of federalism - venue shopping, policy innovation and learning - can indeed be harnessed to enhance gender equality' (Chappell \& Costello 2011: 645). Others suggest that women's interests, along with those of other groups, may not necessarily be best served by uniform national approaches, homogenised legal standards or other universalist preferences which have underpinned the 'science' of law since the century of Australia's establishment, but can themselves carry gendered qualities (see e.g. Condorcet's 1811 view that since 'truth, reason, justice, the rights of man, the interests of property, of liberty, of security, are in all places the same... [a] a good law should be good for all men': Hollander 2011). For some scholars, at least in theory, the decentralist potential of federal structures retains an "edge over national level policy making' by offering higher levels of 'opinion-policy congruence, the ability to more accurately align community sentiment with policy’ (Hollander 2011).

The third school of thought, not necessarily inconsistent with either of the preceding, is a 'conditional' approach - that it is not federalism per se which has either positive or negative 
consequences for women, but the specific ways in which federal (and non-federal) systems are organised, achieving different effects across different institutional arenas, sectors, periods and locations. Thus Chappell and Curtin (forthcoming, p.4) also see circumstances where federalism's benefits may be overblown, inhibiting progressive policy-making by placing power in the hands of entrenched, parochial elites, and not providing effective opportunities for greater participation even when capacity for legal diversity and innovation clearly exists.

Like anyone else, women may express satisfaction with their institutions even if their interests are not, in fact, being served. Nevertheless, a first level of variation in the attitudes of women and men indicates that most women do value at least the capacity for more localised policy diversity and participation which federal systems theoretically provide. In the United States, gender has 'typically not made much of a difference' in levels of federal political culture, but the studies have nevertheless detected significantly stronger faith in lower levels of government among women than men, and stronger faith in the federal level among men than women (Cole et al 2004: 210). In Australia, similar results can be seen. In 2010, asked which of the three current levels of government they thought was 'most effective at its particular job', only 38 per cent of women nominated the federal government (as against 51 per cent of men), while 32 per cent of women nominated local government (as against 22 per cent of men). State government was nominated as most effective by 19 per cent of women, and 16 per cent of men.

The greater value placed by Australian women on decentralised institutions - on average - flows through to their preferences regarding the future of the federal system. Local government is currently entirely a State constitutional creation, but there is recurring pressure for it to be formally recognised in the national Constitution (see Brown 2008; McGarrity \& Williams 2010; Commonwealth of Australia 2011). The Australian survey recorded significantly greater support 
for this proposition among female (57 per cent) than male (45 per cent) respondents. ${ }^{4}$ Statistically significant differences in this direction were recorded for every State. While it may be inaccurate to assume that women are more attracted to participate in and support 'local' rather than 'national' levels of government (Sawer \& Vickers 2010), this evidence suggests that local institutions are nevertheless perceived as important, even when - as in Australia - they have a reputation as a bastion of parochial male elites.

Similarly, female respondents painted a different picture to that of men, on average, when it came to the preferred structure of their system of government in the future, 'twenty years from now'. The proportion of women favouring structural reform (73 per cent in 2010) was similar to the national mean (75 per cent), but their preferred reforms differed from male respondents. A slightly higher proportion of women ( 24 per cent as against 20 per cent of men) would retain the same system as today. The single most preferred reform option for women remained abolition and/or replacement of the States, but was not as strongly supported relative to other possibilities (24 per cent of women as against 30 per cent of men). Instead, women were also likely to favour other decentralist options, including creating more States, or new regional governments as a fourth tier (15 per cent of women, as against 9 per cent of men). Women were much less likely than men to favour the ultra-centralist scenario of abolishing all levels other than the national government (4 per cent of women, as against 7 per cent of men).

This apparent preference for decentralised governance among most women, to a higher degree than men, returns us directly to questions of federal political culture. The principle of decentralism is plainly core to assumed values of federalism, tending to unify them all. Livingstone (1952: 90) described the direct relation between the strength of 'demands for the protection and articulation of diversities' and the degree of decentralisation offered by federal 
institutions; while Saunders (2001: 130) identifies the fact that 'power constitutionally is decentralised' - at least in theory - as the single most defining feature of federal systems.

To test this in-principle attachment to decentralism, the Australian survey collected reactions to the governance principle of 'subsidiarity' - typically understood to mean that matters should be dealt with by the lowest level of government practicable (see e.g. Twomey \& Withers 2007: 4, 28). The relevant question asked respondents to choose between a decentralist statement based on this principle, and a reverse concept that it is generally better for decisions to be made at higher levels of government. Again, significantly greater support for the decentralist statement was found among female (49 per cent) than male (40 per cent) respondents. Support for the centralist statement ran at 55 per cent among men, and 44 per cent among women. ${ }^{5}$

Given these results, what extra light does an analysis of federal political culture cast on current perceptions of federalism's performance? Unsurprisingly, the results from the 2010 Australian survey suggest that on average, women also share a relatively strong federal political culture one that is possibly stronger than the male population. As noted earlier in Table 2, similar proportions of women and men were counted as federalists and non-federalists overall, but a significantly higher proportion of women (14 per cent) fell into the highest category of 'strong federalists' than men (9 per cent). Somewhat more men, and fewer women, also counted as 'conflicted' federalists ( 20 per cent of women, as against 24 per cent of men). In real terms, these results suggest that of the almost two million adult Australians who were strong federalists in 2010, slightly more than three in five were women, and less than two in five were men. In four of the six States - NSW, Queensland, South Australia and Tasmania - women outnumbered men in this category at a ratio of more than two to one. Western Australia was the only State where this result did not hold, and men instead outnumbered women among the strong federalists. 
The presence of geographic differences raises the question of the relative degree of the effects. Western Australia still averaged as having the strongest federal political culture, despite this result by sex; and was also the only State in which women were more likely than men to favour the centralist over the decentralist statement, when asked about the principle of subsidiarity. To test the relative significance of different factors, the results at Table 2 were converted to an interval measure (in lieu of a scale) to permit analyses of variance. ${ }^{6}$ A univariate analysis of variance confirmed that factors other than gender are also predictors of federal political culture, with more significant variations found between those of greater and lesser age, and different States of residence. Nevertheless, the same analysis revealed little interaction effect between the variables, showing they all contribute and that gender, too, remains a factor. What is likely, and deserving of further research, is that particular factors in different jurisdictions are impacting on women's attitudes towards federalism in different ways. This is consistent with conclusions that the responsiveness of federal systems to women's interests is highly context dependent.

\section{INTUITION VERSUS REALITY?}

For scholars convinced that federal systems generally disadvantage women, there may be different explanations for the average relative strength of federal political culture among Australian women. One is that fewer women than men may possess sufficient political knowledge or experience of the system in practice, to make a truly informed assessment (Denemark \& Sharman 1994: 85-6). However, analyses of variance tend against the conclusion that the results in the previous section stem from lower political efficacy or social participation. Slightly more female respondents ( 14 per cent) than men ( 9 per cent) were prepared to admit that they had never heard of the Australian Constitution, but these respondents were not the locus of 
stronger federal culture. Instead, stronger federal culture tended to be evidenced by women with higher levels of education, participation in the paid labour market and engagement with most types of community and political organisations.

The most important lesson from an analysis of constitutional values, as measured here, lies in another possible explanation. The results suggest that the relative strength of federal political culture among Australian women reflects attachment to particular features of the federal system in theory, or potential, more than it reflects any perceived experience of reality. As noted earlier in Table 1, the particular factor that caused female respondents to more strongly occupy the highest category of federalists was the greater, and less conflicted, value that many women attached to the crucial attribute $(b)$, legal diversity: the system's capacity to allow 'different laws in response to varying needs and conditions in different parts of Australia'. Fifty-nine per cent of women found this to be a desirable feature, as against 53 per cent of men. In particular, women were significantly more likely to see this feature as highly desirable, with a ten point difference between genders. It should not be forgotten that substantial proportions of women, like men, do not value legal diversity. However, the average results are consistent with the data regarding perceived effectiveness of levels, reform preferences, and the principle of decentralism.

This stronger valuation of legal diversity has implications beyond policy areas with direct significance for gender equity and equality, such as domestic and community violence, child care and early education. While these areas may well influence the results, the fact is that capacity for policy and legislative diversity is also central to the federalism's legitimacy as a responsive system across the board. The results are thus likely to also reflect women's desires more generally, given that 'all policies impact on men and women's lives in one way or another', 
whether it be in "community" services or in transport, infrastructure, health, employment, economic development, productivity or ecological sustainability (Chappell et al 2011: 231).

The crucial question becomes whether, if women see greater potential than men in decentralised institutions and institutionalised diversity, these desires are being realised in the federal system's perceived performance. The reform preferences noted earlier, suggest it may be otherwise. A final finding confirms that whatever the promise, Australian women are not more likely than men to be persuaded that the system is delivering in practice, as against principle. Overall, citizens' satisfaction with their federal system can be gauged from a combination of respondent views regarding the system's general and specific operations, together with the desirability or otherwise of principles on which it is founded (see Brown 2012b, Table 2). On one hand, in the 2010 survey, female citizens were less likely than men (32 per cent as against 39 per cent) to express an initial view that the current system 'with three main levels' did not work well. However, combined with other salient views regarding the foundations and performance of the system, equal proportions of men and women (87 per cent in total) held an overall negative or adverse perception of the system as a whole. The reason for this result is that female respondents were more likely (43 per cent of women, as against 36 per cent of men) to nominate at least one key feature of the federal system as not being achieved well in practice.

Table 3 highlights that the key feature of the federal system which women were more likely to perceive as being under-achieved or under-released in practice, was exactly that which they were more likely to value in theory: the key attribute (b), capacity for legal diversity. A bare majority of those women (52 per cent) who saw legal diversity as desirable, went on to agree in a subsequent question that the system achieved it at least 'quite well'. Almost as many did not. When viewed as part of the overall perceptions of citizens towards their system, this higher in- 
principle faith but lower satisfaction with performance, also marks out women as, on average, holding a different view of the problem to that of men, even when tending to a similar ultimate judgement overall.

Insert Table 3 about here.

Why do many women, in particular, see the promise of legal diversity as being under-achieved in Australia? The answers depend on further research, but may the effect of State governments bowing to, or being overridden by, pressures for national uniformity, or the inability of federal legislation to deliver tailored responses in an alternative form. Alternatively, or in addition, the results may reflect real or perceived limits on the capacity of State institutions to deliver effectively tailored legislative solutions, even if examples exist of where this has occurred. As Gray (2010: 23) notes - whatever the theory - federalism does not necessarily result in high levels of decentralisation, 'as illustrated by the Australian case with its financially dependent State and Territory governments and extremely weak local government'. The results bear out Cheryl Saunders' (1995: 62) reminder that 'in some cases, the effects of federalism may be obtained in the absence of fully federal constitutional arrangements', but also her warning that in other countries, 'apparently federal in form, key benefits of federation may be missed, representing the worst of both worlds.'

The results here tend to confirm the relevance of this last observation to the Australian system, especially as viewed through the eyes of the average female respondent. The differences in view by gender tend to reinforce the particular interests of many women in a more decentralised, socially responsive federal system, but also point more sharply to generally held concerns that 
present institutional arrangements are under-performing on this score. As indicated earlier, it also seems that women are slightly less concerned than men with complaining about or changing the formal architecture, on an assumption this itself will bring better results. However, their similar overall preference for reform, and slightly clearer alignment between values and preferences as to the necessary directions for reform, appear to make women's attitudes a particularly salient barometer for the system as a whole. The results tend to confirm that the Australian debate is less about whether the system will remain federal in theory, than its practical shape, and especially whether it can evolve towards a more effective framework of sub-national governance.

\section{CONCLUSION}

This article has used results from the Australian Constitutional Values Survey to present exploratory insights into federal political culture in Australia, comparing men's and women's responses as a means of highlighting key reform challenges. While commentators will continue to debate the meaning and best ways of measuring federal political culture, these results join the North American scholarship in demonstrating the feasibility and utility of such research as an analytic tool.

The development of further and better measures of the values that citizens place on the operations of multi-levelled systems is a necessary precondition for effective charting of the arguments, imperatives and potentials for reform. Here, analysis by gender has proved especially useful. While it is not the only significant factor in differences in federal political culture, nor even necessarily the most significant, the results highlight that much reform pressure in Australia has less to do with reactions against federalism in principle, than the ongoing search for scales of 
governance which align with community needs and identities. The conundrum of lower-thanexpected support for legal diversity across the population overall, brings to a head the question of what kind of governance citizens want and need, if neither federal nor state structures alike are proving sufficiently responsive to the needs of communities. Evidence that women, on average, place higher and less conflicted value than men on this key attribute, but are also more likely to question its realisation in practice, raises new departure points.

The data also indicate that at least in 2010, one half of Australian society - women - was somewhat more federalist than the other. This is in terms of both attachment to federalist values, and how those values should be prosecuted in practice. Differences in reform preferences, including higher support for constitutional recognition of local government, further suggest that the challenges of federal reform are ones to which many women are particularly attuned. The results support arguments for increasing women's participation not simply in policy reform, but governance reform more generally. If this argument is accepted, another should begin about how further to explain, and what more to learn from, apparent differences in perception and preference. In any society, if assumed values of federalism are to be realised, there is surely reason to listen to what the strongest, clearest federalists are saying. 


\section{REFERENCES}

Brown, Alexander J (A J) (2004). 'One Continent, Two Federalisms: Rediscovering the Original Meanings of Australian Federal Political Ideas' (2004) 39 Australian Journal of Political Science 485.

Brown, A J (2006). 'The Constitution We Were Meant to Have: Re-examining the Strength and Origins of Australia's Unitary Political Traditions', in Kay Walsh (ed), Democratic Experiments: Lectures in the Senate Occasional Lecture Series, Department of the Senate, Parliament House, Canberra.

Brown, A J (2008). 'In Pursuit of the "Genuine Partner": Local Government and Federal Constitutional Reform in Australia' (2008) 31 University of New South Wales Law Journal 435.

Brown, A J (2009). 'Thinking Big: Public Opinion and Options for Reform of Australia's Federal System' (2009) 4 Public Policy 30.

Brown, A J (2012 a). 'Measuring the Mysteries of Federal Political Culture in Australia' in Paul Kildea, Andrew Lynch \& George Williams (eds), Tomorrow's Federation: Reforming Australian Government, Federation Press, Sydney.

Brown, A J (2012 b). 'Escaping Purgatory: Public Opinion and the Future of Australia's Federal System', in Nicholas Aroney, Gabrielle Appleby and Thomas John (eds), The Future of Australian Federalism: Comparative and Interdisciplinary Perspectives, Cambridge University Press, forthcoming.

Chappell, Louise \& Mayet Costello (2011). 'Australian Federalism and Domestic Violence Policy-Making', Australian Journal of Political Science 46(4): 633-650.

Chappell, Louise, Deborah Brennan \& Kim Rubenstein (2012), 'Australian Intergovernmental Relations: A Gender and Change Perspective', in Paul Kildea, Andrew Lynch \& George Williams (eds), Tomorrow's Federation: Reforming Australian Government, Federation Press, Sydney.

Chappell, Louise \& Jennifer Curtin (2011), 'State architectures and gendered policy making in Australia and New Zealand', Paper presented to the Australian Political Studies Association Conference, Australian National University, 26 - 28 September 2011.

Cole, Richard L, John Kincaid and Alejandro Rodriguez (2004). 'Public Opinion on Federalism and Federal Political Culture in Canada, Mexico, and the United States' (2004) Publius 34(3): 201.

Commonwealth of Australia (2011). Expert Panel on Constitutional Recognition of Local Government: Final Report, Department of Regional Australia, Regional Development and Local Government, Canberra <www.localgovrecognition.gov.au>.

Denemark, David \& Campbell Sharman (1994). 'Political efficacy, involvement and trust: testing for regional political culture in Australia', Australian Journal of Political Science 29: 81-102. 
Duchacek, Ivo (1987). Comparative federalism: The territorial dimension of politics, University Press of America, New York.

Fafard, Patrick, François Rocher \& Catherine Côté (2010). 'The Presence (or Lack Thereof) of a Federal Culture in Canada: The Views of Canadians', Regional \& Federal Studies 20(1): $19-43$.

Galligan, Brian (1995). A Federal Republic: Australia's Constitutional System of Government, Cambridge University Press.

Gray, Gwendolyn (2010). 'Federalism, Feminism and Multilevel Governance: the Elusive Search for Theory?', in Melissa Haussman, Marian Sawer and Jill Vickers (eds), Federalism, Feminism and Multilevel Governance, Ashgate Publishing.

Hollander, Robyn (2011). 'Federalism and the Moral Policy Dilemma', Paper presented to the Australian Political Studies Association Conference, Australian National University, 26 28 September 2011.

Holmes, Jean \& Campbell Sharman (1977). The Australian Federal System, Allen \& Unwin, Sydney.

Inman, Robert (2007) 'Federalism's Values and the Value of Federalism' (2007) 53(4) CESifo Economic Studies 522.

Kincaid, John (1995). 'Values and Value Tradeoffs in Federalism' (1995) Publius 25 (2): 29-44.

Kincaid, John \& Richard L Cole (2010). 'Citizen Attitudes toward Issues of Federalism in Canada, Mexico, and the United States' (2011) Publius 41 (1): 53-75.

Livingston, William S (1952). 'A note on the nature of federalism', (1952) Political Science Quarterly 67 (March): 81-95, at p.90; as quoted by John Kincaid \& Richard L Cole, 'Citizen Attitudes toward Issues of Federalism in Canada, Mexico, and the United States' (2011) 41 Publius 53, at p.67.

McGarrity, Nicola \& George Williams (2010). 'Recognition of Local Government in the Australian Constitution’ (2010) 21 Public Law Review 164.

Saunders, Cheryl (1995). 'Constitutional Arrangements of Federal Systems', Publius 25 (2): 6180 .

Saunders, Cheryl (2000). 'The Implications of Federalism for Indigenous Australians', in Yash Ghai (ed), Autonomy and Ethnicity: Negotiating Competing Claims in Multi-Ethnic States, Cambridge University Press.

Saunders, Cheryl (2001). 'Dividing Power in a Federation in an Age of Globalisation' in Charles Sampford and Tom Round (eds.), Beyond the Republic: Meeting the Global Challenges to Constitutionalism, Federation Press, Sydney.

Sawer, Marian \& Jill Vickers (2010). 'Introduction: Political Architecture and its Gender Impact', in Melissa Haussman, Marian Sawer and Jill Vickers (eds), Federalism, Feminism and Multilevel Governance, Ashgate Publishing.

Smith, Rodney (2001). Australian Political Culture, Frenchs Forest, Pearson Education.

Twomey, Anne and Glenn Withers (2007), Australia's Federal Future: Delivering Growth and Prosperity, Federalist Paper 1, Council for the Australian Federation. 
Vickers, Jill (2010). ‘A Two-Way Street: Federalism and Women's Politics in Canada and the United States', Publius 40(3): 412-435.

Vickers, Jill, Melissa Hausmann and Marian Sawer (2010). 'Conclusion' in Melissa Haussman, Marian Sawer and Jill Vickers (eds), Federalism, Feminism and Multilevel Governance, Ashgate Publishing. 
Table 1 Desirability of features of a multi-levelled system of government (Australia) (2010, n=1100)

Question: '[T]hinking about having different levels of government. For each of the following, please say if you think it is a desirable feature, or an undesirable feature of having different levels of government.'

\begin{tabular}{|l|l|c|c|c|c|}
\hline & $\%$ & Desirable & Undesirable & \begin{tabular}{c} 
Neither \} $\\
{\text { don't know }}$ & Total \\
\hline$a$ & $\begin{array}{l}\text { Having power divided up between } \\
\text { different levels of government }\end{array}$ & 67.5 & 26.9 & 5.5 & 100.0 \\
\hline$b$ & $\begin{array}{l}\text { Allowing different laws in response to } \\
\text { varying needs and conditions in different } \\
\text { parts of Australia }\end{array}$ & $56.3 *$ & 40.7 & 3.3 & 100.0 \\
\hline$c$ & $\begin{array}{l}\text { Being able to elect different political } \\
\text { parties at different levels of government }\end{array}$ & 81.7 & 15.2 & 3.1 & 100.0 \\
\hline$g$ & $\begin{array}{l}\text { Different governments arguing over who } \\
\text { is responsible for a particular problem }\end{array}$ & 20.9 & 75.9 & 3.3 & 100.0 \\
\hline
\end{tabular}
\end{tabular}

* Note: 59.1 per cent of female respondents rated this item as desirable, as against 53.4 per cent of male respondents - a statistically significant difference at the $\mathrm{p}<.05$ level $(0.039, \mathrm{df}=4)$ using Pearson Chi-Square test. 
Table 2 Australian federal political culture - an overview $(2010, \mathrm{n}=1100)$

\begin{tabular}{|l|c|}
\hline$\%$ & \\
\hline $\begin{array}{l}\text { 1. Strong federalists } \\
(a, b, c, g \text { all desirable })\end{array}$ & $11.7 *$ \\
\hline $\begin{array}{l}\text { 2. Clear federalists } \\
(a \& b \text { desirable, } c / g \text { undesirable/ dk })\end{array}$ & 32.0 \\
\hline $\begin{array}{l}\text { 3. Conflicted federalists } \\
(a \text { desirable, } b \text { undesirable, } c \& g \text { any })\end{array}$ & 22.2 \\
\hline $\begin{array}{l}\text { 4. Conflicted non-federalists } \\
(a \text { undesirable, } b \text { desirable, } c \& g \text { any })\end{array}$ & 9.8 \\
\hline $\begin{array}{l}\text { 5. Clear non-federalists } \\
(a \text { \& } b \text { undesirable, } c \& g \text { any })\end{array}$ & 11.3 \\
\hline $\begin{array}{l}\text { 6. Strong non-federalists } \\
(a, b, c, g \text { all undesirable })\end{array}$ & 4.6 \\
\hline Don't know $(a$ \&/or $b)$ & 8.3 \\
\hline Total & 100.0 \\
\hline
\end{tabular}
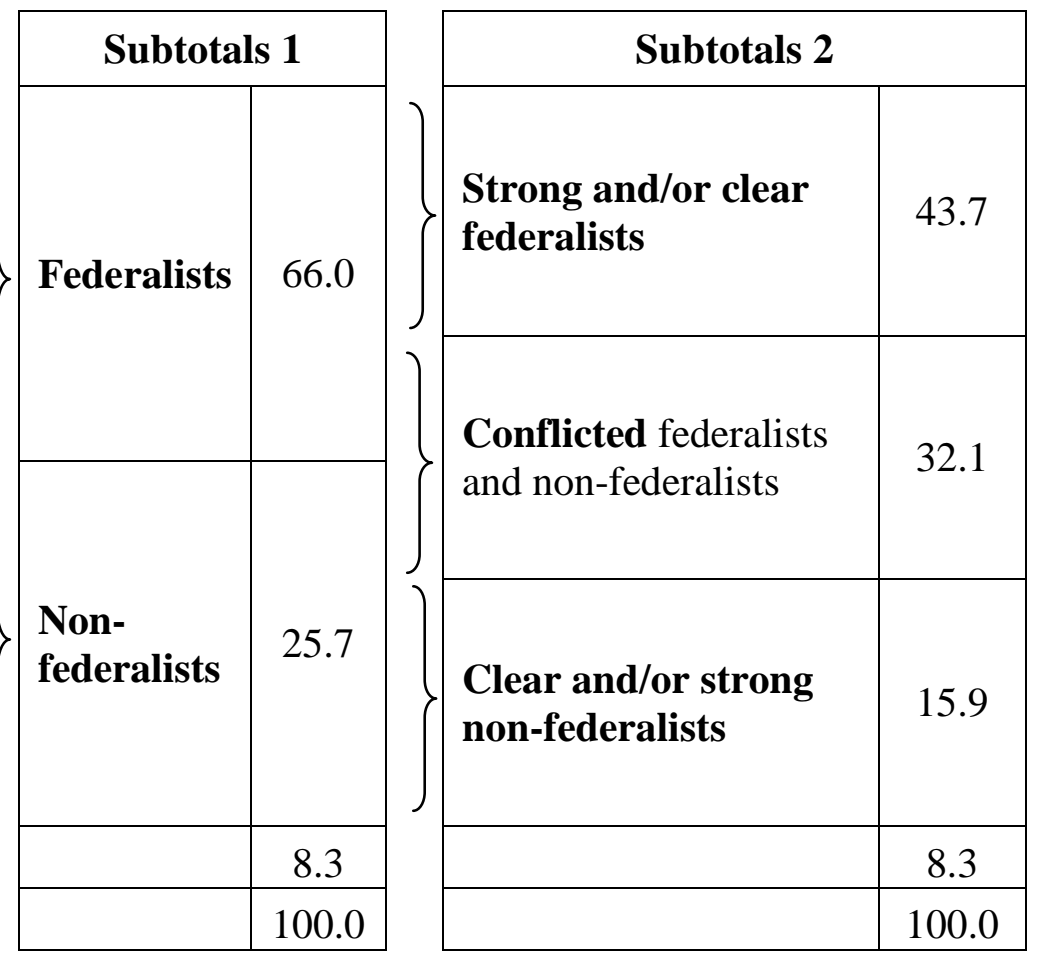

* Note: 14.2 per cent of female respondents fell into the 'strong federalist' category, as against 9.1 per cent of male respondents - a statistically significant difference at the $\mathrm{p}<.05$ level $(0.029, \mathrm{df}=2)$ using Pearson Chi-Square test. 
Table 3 How well are key features of a multi-levelled system of government being achieved? (2010)

Question: If feature in Table 1 selected as desirable -- 'For each of the following, please say if you think our system of government does it very well, quite well, not very well, or not at all well.'

\begin{tabular}{|l|l|l|c|c|c|c|c|}
\hline & \multicolumn{1}{|c|}{$\%$} & & $(\mathrm{n})$ & Well & Not well & $\begin{array}{c}\text { Neither } \\
\text { don't know }\end{array}$ & Total \\
\hline $\boldsymbol{b}$ & $\begin{array}{l}\text { Allowing different laws in response to } \\
\text { varying needs and conditions in } \\
\text { different parts of Australia }\end{array}$ & $\begin{array}{l}\text { Male } \\
\text { liffemale }\end{array}$ & $(288)$ & $\boldsymbol{*} \mathbf{5 7 . 9}$ & $* 40.2$ & 1.9 & 100.0 \\
\cline { 2 - 9 } & All & $(606)$ & $\mathbf{5 4 . 6}$ & $\mathbf{4 3 . 7}$ & 1.7 & 100.0 \\
\hline
\end{tabular}

Note: *Statistically significant differences at the $\mathrm{p}<.05$ level using Pearson Chi-Square test. 
${ }^{1}$ The 2008 and 2010 Australian Constitutional Values Surveys were made possible by the Australian Research Council through Discovery Project 0666833. The author thanks the ARC and his project colleagues, Ian Gray (Charles Sturt University), Cheryl Saunders (University of Melbourne) and David Brunckhorst (University of New England), as well as Tony Dunn (Charles Sturt University), Andrew Parkin (Flinders University), Anne Twomey (University of Sydney), Ron Levy (Griffith University) and John Davis and Cassandra Marks (Newspoll Limited) for contributions to questionnaire design. The author also thanks Louise Chappell, Marian Sawer, John Kincaid and the anonymous reviewers for helpful comments on this article, and Helen Klieve for assistance with statistical analysis. Further project details are available at <www.griffith.edu.au/federalism>.

${ }^{2}$ The Surveys consisted of twenty minute telephone surveys conducted nationally of Australian citizens and permanent residents aged eighteen years and over. Newspoll Limited was contracted to conduct the Surveys, with respondents selected via a stratified random sampling process using random digit dialling ('RDD'), according to quotas set by statistical division, with one individual selected in each household by a 'last birthday' screening question, supported by a system of appointments and call-backs. For representativeness, results reported here are post-weighted according to population distribution using Australian Bureau of Statistics data on age, highest level of schooling completed, sex and area. In line with standard sampling variances, national results for both samples (May 2008, n=1201; March 2010, $\mathrm{n}=1100$ ) are estimated as accurate to plus or minus 3 per cent or better, to a 95 per cent level of confidence.

${ }^{3}$ If added to form a single scale, the items show a Cronbach's Alpha co-efficient of maximum 0.370 (unreliable).

${ }^{4}$ Respondents were told 'At the moment, the [Australian] Constitution does not actually mention or officially recognise that local government exists in Australia', then asked which of the following came closest to their view: 'The existence of local government should be officially recognised in the Constitution' (female 57.3 per cent; male 44.5 per cent), or 'There is no real benefit in making this change to the Constitution' (female 41.1 per cent; male 53.1 per cent). These differences are statistically significant at the $p<.001$ level using Pearson Chi-Square test. ${ }^{5}$ Respondents were asked 'Thinking of the federal government as being the highest level of government, and state and then local as being lower levels of government; which one of the following comes closest to your view about where decisions should be made?': 'It is better for decisions to be made at the lowest level of government competent to deal with the decision' (decentralist) (female 48.7 per cent; male 40.2 per cent), or 'It is better for as many decisions as possible to be made at the higher levels of government' (centralist) (female 43.7 per cent; male 54.5 per cent). These differences are statistically significant at the $\mathrm{p}<.05$ level using Pearson Chi-Square test.

${ }^{6}$ This was an interval measure from 0 to $5,0=$ strong non-federalists, $5=$ strong federalists, with a mean of 3.10 and a standard deviation of $1.346(n=1013)$. 